\title{
TURUNNYA KEKUASAAN REZIM ORDE BARU DALAM PERSPEKTIF TEORI KONFLIK
}

\author{
Halimah Humayrah Tuanaya \\ Fakultas Hukum Universitas Pamulang \\ Email : dosen01416@unpam.ac.id \\ Abstrak
}

Konflik merupakan realitas sosial yang tidak dapat dihindari. Perbedaan kepentingan antara kelompok penguasa orde baru dan kelompok masyarakat yang didominasi, telah menghasilkan konflik yang berujung gejolak kekerasan. Walaupun secara konseptual konflik memiliki dampak positif dalam menghadirkan perubahan sosial di masyarakat, namun analisa atas tumbangnya rezim orde baru perlu dilakukan guna mencari formula terbaik dalam menyikapi konflik kekuasaan yang mungkin terjadi di kemudian hari. Serangkaian kebijakan yang diambil oleh kelompok penguasa orde baru dalam merespon konflik menjadi masalah yang akan dianalisa pada penelitian ini, sekaligus mencari solusi efektif yang dihasilkan dari penggunaan antithesis konsep teori konflik dalam memandang tumbangnya rezim orde baru. Penelitian ini menggunakan metode penelitian normatif, dengan pendekatan yang bersifat yuridis-normatif, serta menggunakan bahan hukum sekunder. Hasil dari penelitian ini menunjukkan; pertama, hal-hal yang menjadi cikal bakal tumbangnya rezim orde baru menurut asumsi teori konflik, seperti dominasi kelompok penguasa orde baru atas pembentukan dan penegakan hukum; tertutupnya ruang negosiasi untuk mencapai konsensus atas konflik kepentingan yang ada; dan lain sebagainya, telah membawa perubahan sosial atas nama reformasi. Kedua, penggunaan antithesis konsep teori konflik, menunjukkan adanya solusi dalam upaya menyikapi konflik kekuasaan, diantaranya dengan membuka ruang-ruang negosiasi dalam menghasilkan konsensus dari berbagai kelompok kepentingan masyarakat.

Kata Kunci : kekuasaan; teori Konflik; orde baru

\begin{abstract}
Conflict is a social reality that can not be avoided. Differences in interests between the New Order ruling group and the dominated community groups have resulted in conflicts that have led to violent upheaval. Although conceptually the conflict has a positive impact in bringing about social change in society, but an analysis of the fall of the new order regime needs to be done in order to find the best formula in dealing with power conflicts that might occur in the future. A series of policies taken by the New Order ruling
\end{abstract}


group in responding to conflicts became a problem that will be analyzed in this study, as well as finding effective solutions resulting from the use of the antithesis of conflict theory concepts in looking at the fall of the new order regime. This research uses normative research methods, with a juridicalnormative approach, and uses secondary legal material.The results of this study indicate; first, the things that became the forerunner to the fall of the New Order regime according to the assumptions of conflict theory, such as the dominance of the New Order ruling group over the formation and enforcement of the law; closed negotiation space to reach consensus on existing conflicts of interest; and others, have brought social change in the name of reform. Second, the use of the antithesis of the concept of conflict theory, shows the existence of solutions in efforts to address power conflicts, including by opening negotiation spaces in generating consensus from various interest groups in the community.

Keywords: power; conflict theory; the new order

\section{Pendahuluan}

Berakhirnya rezim otoriter Orde Baru yang selama 32 tahun dipimpin Suharto merupakan puncak kemarahan rakyat atas berbagai kebijakannya. Rezim otoriter ini tidak lagi mampu menciptakan suasana kehidupan masyarakat yang terkendali. Berbagai nilai-nilai penguasa sengaja dimasukkan dalam berbagai peraturan-perundang-undangan yang dilakukan dengan tujuan guna melanggengkan kekuasaan Soeharto bersama dengan kroni-kroninya dalam struktur kepemimpinan Negara Republik Indonesia. Beberapa kebijakan yang sengaja diciptakan guna mengekang pola tingkah laku rakyat agar tidak berbuat sesuatu yang dapat mengancam kelangsungan kepemimpinannya seperti, larangan-larangan mengkritik pemerintah baik dalam bentuk lisan, tulisan atau secara visual, larangan bagi pegawai Negeri Sipil untuk bebas memilih partai dengan mengadakan serangkaian orientasi atau penyuluhan yang secara tegas memerintahkan aparatur negara untuk hanya memilih partai penguasa, dll disadari kelompok-kelompok tertentu sebagai suatu tindakan kediktaktoran penguasa yang hanya menghasilkan suatu negara demokratis semu. Sehingga saat berbagai krisis melanda, harga bahan-bahan pokok malambung tinggi dan tidak terjangkau oleh kemampuan daya beli masyarakat, hal ini dengan mudah menyulut amarah masayarakat yang mulai disadarkan dengan serangkaian aksi-aksi provokasi yang ditunggangi kelompokkelompok tertentu yang kontra terhadap pemerintah rezim orde baru. 
Secara singkat berakhirnya rezim Orde Baru dapat digambarakan sebagai berikut; ${ }^{1}$ Pada Maret 1998 MPR menggelar Sidang Umum dan memilih Soeharto dan BJ Habibie sebagai Presiden dan Wakil Presiden untuk masa jabatan 1998-2003. Mei 1998 para mahasiswa dari berbagai daerah menggelar demonstrasi dan aksi keprihatinan yang menuntut penurunan harga barangbarang kebutuhan pokok, penghapusan korupsi, kolusi dan nepotisme, serta mundurnya Soeharto dari kursi kepresidenan. Aksi demostrasi pada 12 Mei 1998 menewaskan empat orang mahasiswa Universitas Trisakti. Peristiwa itu kemudian mengobarkan semangat para mahasiswa untuk mengadakan aksi secara besar-besaran. Akibat aksi tersebut, pada 13-14 Mei 1998 Jakarta dan sekitarnya dilanda kerusuhan masal yang melumpuhkan hampir seluruh kegiatan masyarakat. Sejumlah gedung dibakar, penjarahan terjadi pada sejumlah toko, sejumlah orang turut terbakar dan pemerkosaan terjadi atas perempuan etnis tertentu. Selanjutnya pada 19 Mei 1998 mahasiswa dari sejumlah perguruan tinggi menduduki Gedung Dewan Perwakilan Rakyat (DPR)/ Majelis Permusyawaratan Rakyat (MPR). Disaat bersamaan terjadi aksi demonstrasi disejumlah daerah dan kota-kota besar lainnya. Hingga akhirnya, atas anjuran Harmoko sebagai Pipinan DPR/ MPR, pada 21 Mei 1998 Soeharto mengundurkan diri dari jabatannya dan mendudukkan BJ Habibie yang semula Wakil Presiden menjadi Presiden.

\section{Permasalahan}

Berdasarkan latar belakang yang telah diuraikan di atas, pokok permasalahan dalam tulisan ini adalah Bagaimana turunnya rezim orde baru dianalisis menggunakan asumsi teori konflik ? Bagaimana penggunaan antitesis teori konflik sebagai dasar penentuan solusi atas konflik dominasi kekuasaan untuk mencapai perubahan sosial tanpa gejolak kekerasan?

\section{Metode Penelitian}

Penelitian ini menggunakan metode penelitian normatif, dengan pendekatan yang bersifat yuridis-normatif. Dengan menggunakan metode penelitian tersebut, penelitian ini akan menggunakan bahan hukum sekunder Bahan Hukum Sekunder, yaitu bahan hukum yang diperoleh dari buku teks, jurnal, pendapat para sarjana, kasus-kasus hukum, serta simposium yang dilakukan para sarjana terkait dengan penelitian ini

1 B. R. Pudya, Timbulnya Gerakan Reformasi 1998 di Indonesia, Ganesha Study Club, http://pelitabaraapi.blogspot.com, diakses pada 13 Desember 2009. 


\section{Pembahasan}

\section{Teori Konflik Sebagai Dasar Analisis Menelaah Turunnya Orde baru}

Sejumlah "asumsi" yang ada dalam teori konflik Penulis pandang sangat relevan dalam menjawab kausa kejahatan yang terjadi pada peristiwa tumbangnya rezim Orde Baru pada 1998. Asumsi teori konflik yang mengatakan bahwa konflik terjadi akibat adanya "pemaksaan kehendak oleh kelompok yang berkuasa". Dalam kaitannya dengan kerusuhan yang terjadi di Tahun 1998, sebelum lahirnya peristiwa tumbangnya rezim Orde Baru, pemerintahan Soeharto bertindak otoriter terhadap rakyat Indonesia yang dilakukan dengan pembentukan berbagai instrumen hukum dan langkahlangkah penegakan hukum yang dinilai sebagai suatu bentuk pemaksaan kehendak penguasa pada saat itu (Soeharto).

Akibat pemaksaan kehendak tersebut, selanjutnya mulai muncul berbagai tindakan "ketidakpatuhan" terhadap nilai-nilai penguasa yang telah diadopsi sebagai standar berperilaku pada masa itu. Berbagai kritik dilontarkan kelompok-kelompok anti pemerintah sebagai bentuk perlawanan, walaupun akhirnya mereka harus dipenjarakan dengan dasar berbagai peraturan perundang-undangan yang sebelumnya sengaja dibentuk guna mempertahankan kepentingan penguasa (pemerintahan rezim orde baru). Tidak sampai disitu, berbagai penelitian menunjukkan bahwa pemerintahan era orde baru telah melakukan berbagai tindakan di luar hukum yang melanggar hak asasi manusia seperti, "penghilangan paksa” sekelompok orang yang secara vocal menentang pemerintah hingga aksi terang-terangan seperti, peristiwa Tanjung Priok dan aksi pendudukan kampus ITB oleh kekuatan militer yang dilakukan dengan tujuan untuk meredam setiap tindakan maupun rencana masayarakat yang membahayakan kelanggengan pemerintahan penguasa pada masa itu.

Peristiwa kerusuhan 1998 meletus akibat serangkaian tindakan yang sengaja dilakukan sebagai bentuk pemberontakan terhadap hegemoni pemerintah oleh kelompok anti pemerintah dengan diikuti berbagai elemen masyarakat yang merasa telah dilemahkan oleh pemerintahan orde baru, baik dalam bidang ekonomi, politik, pendidikan, dll dan semakin distimulasi dengan berbagai fakta yang terungkap dalam rangkaian testimoni korban dan keluarga korban akibat kekejaman pemerintah. Di sisi lain, masyarakat juga mulai "mempersoalkan pembuatan hukum" yang dilakukan pemerintahan pada masa itu. Hukum yang diciptakan dianggap hanya mengakomodir kepentingan-kepentingan penguasa dan dibentuk oleh kelompok pembentuk undang-undang (legislatif) yang tidak lain merupakan kepanjangan tangan dari eksekutif. Sehingga dalam merumuskan suatu kebijakan, Dewan Perwakilan 
Rakyat (DPR) / Majelis Permusyawaratan Rakyat (MPR) yang dianggap sebagai kelompok perwakilan rakyat justru cenderung lebih memperjuangkan aspirasi kelompok eksekutif dibandingkan dengan menjalankan fungsinya sebagai "penyambung lidah rakyat". Selain soal kerelevanan teori konflik dengan peristiwa tumbangnya rezim Orde Baru, teori konflik hemat Penulis lebih kritis dalam menjawab kausa kejahatan yang terjadi pada peristiwa/ suatu masalah dibandingakan dengan teori labeling dan teori radikal. Sebab, teori konflik tidak hanya melihat kausa kejahatan dari sudut pandang ekonomi sebagaimana teori radikal kristis. Teori konflik misalnya berpendapat bahwa sesungguhnya tidak pernah ada konsensus antara kelompok penguasa dan kelompok lemah. Ralf Dahrendorf misalnya, yang berpendapat bahwa consensus dari masyarakat adalah suatu "utopia". Dahrendorf meyakini bahwa paksaan yang ditegakkan dan bukan kerjasama yang mengikat masayarakat bersama. ${ }^{2}$ Di sisi lain, Dahrendorf meyakini bahwa konflik dapat menghasilkan consensus dan integrasi. ${ }^{3}$ Dengan demikian, dapat disimpulkan bahwa pada dasarnya menurut kacamata teori konflik, masyarakat dipersatukan bukan sebab consensus dalam arti sesungguhnya, melainkan dipersatukan oleh pembatasan yang dipaksakan. Dalam konteks rezim orde baru, masyarakat dipersatukan melalui hukum yang dipaksakan. Hal ini sejalan dengan teori Roscoe Pound yang identik dengan kalimat "law as a tool of social engineering" (hukum adalah alat perekayasa sosial). Melalui hukum, masyarakat dapat direkayasa dan diperbaharui sesuai dengan kehendak penguasa yang memegang kewenangan untuk membentuk hukum pada masa itu. Bahkan Mochtar Kusumaatmaja menyebutkan bahwa, di masa kekuasaan Soeharto sempat populer istilah "hukum sebagai alat pembangunan", dikarenakan di masa itu hukum betul-betul berfungsi strategis sebagai alat untuk mensukseskan pembangunan ${ }^{4}$. “...namun rendahnya kesadaran hukum dari para pembuat dan penegak hukum kala itu menyebabkan hukum sebagai alat pembangunan jadi berubah fungsi menjadi hukum sebagai alat untuk mengamankan pembangunan, yang mempunyai konsekuensi munculnya banyak hukum yang sangat represif dan melanggar hak-hak masyarakat, yang mengantarkan banyak aktifis ke rumah penjara atau liang kubur" ${ }^{5}$. Dengan demikian hal ini sesuai dengan asumsi teori konflik bahwa, sejumlah posisi

${ }^{2}$ Topo Santoso dan Eva Achjani Zulfa, Kriminologi, PT RajaGrafindo Persada, Jakarta, 2004, Cet. Ke-4, hlm. 106.

${ }^{3}$ Muhamad Zuldin, M. (2019). Ketimpangan Sebagai Penyebab Konflik: Kajian atas Teori Sosial Kontemporer. TEMALI: Jurnal Pembangunan Sosial, 2(1), 157-183.

${ }^{4}$ Munir Fuady, Teori-Teori Besar (Grand Theory) Dalam Hukum, Kencana Prennamdeia Group, Jakarta, 2013, hlm. 248.

${ }^{5}$ Lathif, N. (2017). TEORI HUKUM SEBAGAI SARANA ALAT UNTUK MEMPERBAHARUI ATAU MEREKAYASA MASYARAKAT. PAKUAN LAW REVIEW, 3(1). 
dalam masyarakat merupakan kekuasaan dan wewenang yang dilegasikan dari satu pihak atas pihak lainnya. Fakta tentang fenomena sosial semacam inilah yang mambawa Dahrendorf pada tesis utamanya yang mengemukakan bahwa pendistribusian wewenang marupakan faktor penentu dari konflik-konflik sosial yang sistematis ${ }^{6}$. Secara umum konflik wewenang dari berbagai macam tipe kelompok yang terkoordinasi dari sistem sosial merupakan sisklus yang tidak akan pernah berakhir, dan ini merupakan kenyataan sosial, sebagaimna yang diyakini oleh Dahrendorf dalam teori konflik ${ }^{7}$.

\section{Penerapan Kebijakan Hukum Pidana Dalam Optik Teori Konflik Telaah Terhadap Turunya Kekuasaan Orde baru}

Secara konseptual, konflik terjadi akibat adanya pertentangan antara dua atau lebih orang, kelompok atau lembaga dalam menginterpretasikan suatu konsep tertentu atau untuk mencapai kebutuhannya. Konflik dapat berkembang di masyarakat dan menghasilkan persepsi negatif antara elemenelemen masyarakat. Dalam kondisi tersebut, masyarakat dalam suasana konflik akan berada dalam kondisi saling curiga, waspada, dan mengkritik satu sama lain bergantung pada sudut pandang dan kebutuhannya di masyarakat. Situasi semacam ini tak pelak akan menimbulkan benih-benih disharmoni dan terjadinya krisis relasi sosial di masyarakat. Sebagai klimaksnya, situasi konflik dapat berujung pada hadirnya kekerasan antar kelompok masyarakat.

Untuk memahami konflik dalam kacamata sosial, harus dibedakan antara konflik dengan kekerasan, keduanya memiliki pengertian dan dampak sosial yang berbeda. Tanpa pengendalian yang baik dan efektif, konflik dapat saja berkembang dan mengarah pada kekerasan sebagaimana digambarkan pada situasi di atas, namun tidak setiap konflik mengandung unsur kekerasan. Dengan demikian dapat disimpulkan bahwa konflik tidak selalu identik dengan kekerasan, namun kekerasan dapat saja timbul akibat konflik. ${ }^{8}$

Selanjutnya, dalam konteks teori konflik, situasi konflik tidak selalu berasumsi negatif dan harus dihindari. Secara konseptual konflik juga dapat membawa pengaruh positif di masyarakat. Masalah yang dihadapi berbagai kelompok masyarakat dalam konflik sosial, justru dapat menjadi alat mengintegrasikan masyarakat dan membawa masyarakat pada suatu pembaharuan sosial yang lebih baik.

\footnotetext{
${ }^{6}$ Judistira K Garna dalam Disertasi Sunarta, Integrasi dan Konflik: Kedudukan Politik Jawara dan Ulama dalam Budaya Politik Lokal, PPS UNPAD Bandung, Bandung, 1997, hlm. 25.

${ }^{7}$ Novri Susan, Sosiologi Konflik: Isu-Isu Konflik kontemporer, Kencana, Jakarta, 2009, hlm. 52, Cetakan Pertama.

${ }^{8}$ Abdul Jamil Wahab, Manajemen Konflik Keagamaan; Analisis latar Belakang Konflik Keagamaan Aktual, Elex Media Komputindo Kompas-Gramedia, 2014, Jakarta, hlm. 6.
} 
Terdapat beberapa asumsi-asumsi dasar dalam teori konflik yang membantu menjawab penyebab timbulnya berbagai tindak pelanggaran hukum dalam tragedy 1998. Menurut Ronald L. Akers misalnya, teori konflik berpandangan bahwa kelompok yang paling berkuasa dapat mengontrol hukum, sehingga nilai-nilai dari kelompok yang berkuasa tersebut diadopsi oleh standar hukum dalam bertingkah laku. ${ }^{9}$ Salah satu tokoh teori konflik, Ralf Dahrendorf mengemukakan bahwa masyarakat pada dasarnya terdiri atas organisasi-organisasi yang saling mendominasi antara satu dengan yang lainnya, masing-masing memiliki tujuan yang serupa yaitu mencapai kepentingannya masing-masing. Hanya saja, dominasi yang berkembang di masyarakat merupakan dominasi yang berdasarkan wewenang atau kekuasaan, sehingga menimbulkan konsekuensi bahwa organisasi yang tidak didominasi harus menerima dan mengakui wewenang dan kekuasaan pihak yang memegang dominasi. Hal ini senada dengan apa yang terjadi pada rezim orde baru, ketika dua kepentingan berbeda dihadapkan dan menghasilkan suatu konflik sosial. Pada satu sisi pihak yang berkuasa berkepentingan untuk mempertahankan kekuasaan dan di sisi lain pihak yang dikuasai memiliki kepentingan berbeda untuk memperoleh kekuasaan ${ }^{10}$.

Pada Rezim Orde Baru, dalam setiap kebijakan yang dikeluarkan selalu dengan alasan dalam kerangka pelaksanaan demokrasi Pancasila. ${ }^{11}$ Namun jika melihat tujuan di balik berbagai kebijakan yang diciptakan, yang sebenarnya terjadi adalah dalam rangka mempertahankan kekuasaan Presiden Suharto dan kroni-kroninya. ${ }^{12}$ Pada masa rezim Orde Baru, kehidupan politik sangat represif, yang ditandai adanya tekanan yang kuat dari penguasa terhadap pihak oposisi dan kelompok kritis lainnya. Rezim Orde Baru membuat UndangUndang Subversif yang dapat menjerat setiap orang atau kelompok yang mengkritik kebijakannya. Menurut Austin Turk kelompok yang memiliki kekuasaan akan menjaga kepetingan-kepentingannya dengan mengkriminalisasikan perbuatan-perbuatan yang mengancam kekuasaanya. ${ }^{13}$ Pendapat Austin inilah yang Soeharto terapkan. Dengan berbagai cara Soeharto membuat kebijakan untuk kelanggengan kekuasaanya. Dengan Undang-Udang Subversi misalnya, nilai-nilai penguasa sengaja diundangkan untuk kepentingan penguasa. Larangan mengkritik pemerintah telah diadopsi

London, hlm. 137

9 Ronald L. Akers, Criminological Theories, Fitzroy Dearborn Publishers, 1999,

10 Kamanto Sunarto, Pengantar Sosiologi, Lembaga Penerbit fakultas Ekonomi Universitas Indonesia, 2004, Jakarta, hlm. 218.

${ }_{11}^{11}$ B. R. Pudya, Timbulnya Gerakan..., Loc.Cit.

12 Ibid

13 Austin Turk, Law as a Weapon in Social Conflict, Social Problems 23 (1976) hlm. 276-291 dalam Freda Adler, et all, Criminology, McGraw-Hill, 1991, New York, hlm. 187. 
menjadi suatu standar berprilaku. Barangsiapa yang mengkritik pemerintah, dianggap telah melakukan suatu tindakan pelanggaran hukum. Tidak hanya dengan Undang-Undang Subversi, pemilihan umum sebagai pesta demokrasi pun direkaysa sedemikian rupa. Mulai pemaksaan untuk memilih Golongan Karya hingga penghilangan surat suara pemilihan umum apabila di suatu daerah Golongan Karya tidak keluar sebagai partai pemenang.

Selain Undang-Undang Subversif rezim Orde Baru juga mengeluarkan kebijakan pelaksanaan Lima Paket Undang-Undang Politik antara lain, Undang-Undang Kepartaian, Undang-Undang Pemilu dan Undang-Undang Susunan DPR/ MPR yang melahirkan demokrasi semu dan menyuburkan korupsi, kolusi, dan nepotisme. Hal ini sesuai dengan kajian yang dilakukan Jusmalia dan Teguh Puja, mengungkapkan bahwa di masa orde baru, "negara menerapkan politik yang sifatnya represif demi menghentikan tindakantindakan yang dianggap subversif terhadap pemerintah" ${ }^{14}$.

Terdapat berbagai studi, baik dari dalam maupun luar negeri yang turut menganalisis kondisi sistem politik di Indonesia pada rezim orde baru. Terdapat berbagai label yang disematkan terhadap situasi politik di masa itu untuk menggambarkan buruknya sistem perpolitikan yang berlaku di masa itu dan dampaknya terhadap berbagai sektor penting di Indonesia, baik ekonomi, hukum, ideologi dan lain sebagainya. Beberapa label ternama yang pernah disematkan dan identik dengan pemerintahan orde baru antara lain, "state qua state" 15 yang dikemukakan Benedict Anderson, "bureaucratic polity" 16 dari Karl D. Jackson, "Bureaucratic Pluralism "1718” oleh Donald Emmerson, "bureaucratic authoritarianism" 19 " oleh Dwight King, dan "limited pluralism"20 yang diberikan oleh William Liddle. Secara umum, walaupun terdapat pendapat yang berbeda diantara para peneliti tersebut dalam memandang situasi politik di Indonesia, namun setidaknya semua berasumsi sama, yaitu

14 Oktaviani, J., \& Pramadya, T. P. Model Negara Kekuasaan: Orde Baru dalam Tinjauan Pemikiran Hobbes dan Niccolo Machiavelli. Indonesian Perspective, 4(2), 175-190.

${ }^{15}$ Syahputra, M. A. D., \& Mahdiana, N. Analisis Buku Teks Sejarah terkait Materi Nasionalisme Dengan Pendekatan Teori Nasionalisme Benedict Anderson. HISTORIKA, 22(2)

${ }^{16}$ Purwoko, B. (2016). Bureaucracy and the Politics of Identity: A Study on the Influence of Ethnicity on the Bureaucrat Recruitment Process in Sorong Selatan Regency, West Papua, Indonesia. Indonesian Journal of Government and Politics, 7(4), 132141.

${ }^{17}$ Syukur, I. (2013). Adat Community in the Village Government: State and Society Relations in Indonesia. ASAS, 5(1).

${ }^{18}$ Zuhro, R. S. (2016). Good Governance dan Reformasi Birokrasi di Indonesia. Jurnal Penelitian Politik, 7(1), 21.

${ }_{19}$ Purwoko, B. (2016). Bureaucracy and the Politics of Identity: A Study on the Influence of Ethnicity on the Bureaucrat Recruitment Process in Sorong Selatan Regency, West Papua, Indonesia. Indonesian Journal of Government and Politics, 7(4), 132141.

${ }^{20}$ Abdi, S. (2007). Muslim Politics and Democracy in Indonesia. Millah: Jurnal Studi Agama, 7(1), 77-93. 
adanya upaya dari pemegang kekuasaan negara di Indonesia pada saat itu untuk menguasai dan mendominasi arena politik yang selanjutnya digunakan sebagai alat kontrol terhadap masyarakat.

Pratikno berpendapat bahwa, pada rezim orde baru sempat terjadi transisi sentralisasi yang semakin mengarah pada individu Soeharto sebagai pemegang kekuasaan. "Apabila oada awal orde baru pemerintah Indonesia di bawah kendali kekuatan militer sebagai institusi, maka sejaka awal 1980-an politik Indonesia semakin tersentralisir pada kepemimpinan personal Soeharto"21.

Masih menurut Ronald L. Akers dalam teori konflik anggota dari kelompok yang lemah, tetap bertingkah laku sesuai dengan norma kelompoknya. ${ }^{22}$ Rezim Orde Baru sebagai penguasa, meskipun membuat kebijakan sesuai dengan kehendaknya namun sekelompok orang tidak mau tunduk dengan kebijakan tersebut. Hal ini adalah wajar mengingat hanya kepentingan-kepentingan kelompok yang berkuasa sajalah yang diakomodir dalam kebijakan tersebut. Kelompok yang lemah/masyarakat hanya dipaksa untuk tunduk pada kebijakan yang dibuat kelompok penguasa.

Kelompok mahasiswa dan lembaga swadaya masyarakat misalnya tetap mengkritisi segala kebijakan rezim Orde Baru tanpa mempedulikan adanya Undang-Undang Subversif. Tidak tunduknya sekelompok orang atas kebijakan penguasa tersebut dianggap oleh penguasa sebagai pelanggaran hukum. Sebagai contoh ketika itu Fadjoel Rachman memprotes kehadiran Menteri Dalam Negeri Rudini di kampus ITB. Rudini dianggap sebagai penjaga kebijakan pertanahan rezim orde baru yang merugikan rakyat. Atas tindakan yang dilakukannya, Fadjroel Rachman dituduh subversive dan kemudian ditahan selama satu tahun sebelum akhirnya divonis tiga tahun penjara.

Penganut teori konflik berpandangan suatu perbuatan dikatakan sebagai suatu tindak pidana tergantung tempat dan waktunya. ${ }^{23}$ Aksi demonstrasi, mengkritik pemerintah dan memprotes kehadiran penguasa yang datang ke suatu tempat seperti pernah dilakukan Fadjoel Rachman yang sudah disebutkan di atas di era rezim Orde Baru dianggap sebagai tindak pidana (subversif). Namun di era demokrasi sekarang ini tidak lagi dianggap sebagai suatu tindak pidana. Aksi demonstrasi dan mengkritik pemerintah merupakan hal yang wajar dan suatu keniscayaan di era demokrasi. Sejumlah peraturan perundang-undangan yang dianggap tidak mendukung iklim demokrasi dicabut, amandemen atau dinyatakan bertentangan dengan Undang-Undang

21 Pratikno, P. (1998). Keretakan Otoritarianisme Orde Baru dan Prospek Demokratisasi. Jurnal Ilmu Sosial dan Ilmu Politik, 2(2), 18-33.

22 Ronald L. Akers, Criminological..., Op Cit., hlm. 137.

23 Freda Adler, et all, Criminology, McGraw-Hill, 1991, New York, hlm. 187. 
Dasar oleh Mahkamah Konstitusi Republik Indonesia sehingga tidak lagi memilki daya ikat.

Topo Santoso dan Eva Achjani Zulfa dalam bukunya Kriminologi, menyebutkan bahwa teori konflik lebih jauh mempertanyakan proses pembuatan hukum itu sendiri. ${ }^{24}$ Menurut penganut teori konflik pertarungan (strugle) merupakan realitas dalam masyarakat untuk tujuan memperoleh dan mempertahankan kekuasaan. Kelompok yang memegang kendali kekuasaan akan berusaha untuk mengontrol pembuatan dan penegakan hukum ${ }^{25}$. Peristiwa tumbangnya rezim Orde Baru pada 1998 merupakan puncak kesadaran masyarakat yang tidak hanya "mengabaikan" begitu saja kebijakan penguasa. Lebih dari itu masyarakat telah sejak lama dan terus menerus mempertanyakan kebijakan yang rezim Orde Baru buat. Sebagai bentuk kontrol atas kebijakan yang rezim Orde Baru buat, sekelompok masyarakat kemudian melakukan aksi demonstrasi menuntut penurunan harga bahanbahan pokok hingga menuntut Soeharto mundur dari jabatannya sebagai presiden pada 1998. Jauh sebelum tumbangnya rezim Orde Baru tuntutan mundurnya Soeharto dari jabatannya sebagai presiden sudah muncul di berbagai tempat. Di Bandung misalnya pernah terjadi Gerakan Lima Agustus ITB (Institut Teknologi Bandung) yang kemudian mengantarkan sejumlah aktivis ke penjara.

Penganut teori konflik menentang pandangan konsesus tentang asal lahirnya hukum pidana dan penegakannya. ${ }^{26}$ Dalam konteks peristiwa tumbangnya rezim Orde Baru pada 1998, masyarakat mulai "melawan" kebijakan Soeharto. Masyarakat berpandangan tidak pernah ada konsensus antara penguasa dan masyarakat tentang segala kebijakan penguasa. Penganut teori konflik mempertanyakan "jika masayarakat sepakat tentang sistim nilai, sebagaimana diyakini para penganut model consensus, maka mengapa begitu banyak orang memberontak?" ${ }^{27}$ Dengan kata lain penganut teori konflik tidak pernah sepakat tentang sistem nilai. Keteraturan yang ada di masyarakat terjadi hanya karena adanya paksaan (koersi). ${ }^{28}$ Kebijakan penguasa merupakan cerminan nilai-nilai penguasa. Hal ini sesuai dengan pernyataan Richard Quinney dalam bukunya Crime and Justice in Society,

${ }^{24}$ Topo Santoso dan Eva Achjani Zulfa, Kriminologi, PT RajaGrafindo Persada, 2004,Jakarta, Cet. Ke-4, hlm. 104.

${ }^{25}$ Sukardi. (2016).Penanganan Konflik Sosial Dengan Pendekatan Keadilan Restoratif. Jurnal Hukum dan Pembangunan, 46(1). 70-89.

26 Ibid., hlm. 105.

27 Richard Quinney dalam bukunya Crime and Justice in Society, Little, Brown, Boston, 1969, pp. 26-30, dalam Freda Adler, et all, Criminology, (New York: McGraw-Hill, 1991), hlm. 186.

${ }_{28}$ Diharjo, S. M. (2019). DINAMIKA PERUBAHAN SOSIAL DALAM TEORI KONFLIK. Jurnal Ilmu Komunikasi dan Bisnis, 5(1), 1-17. 
bahwa "laws do not exis for the collective good; they represent the interest of specific groups that have the power to get them enacted". ${ }^{29}$ Penguasa hanya membuat dan kemudian memaksa masyarakat sebagai kelompok yang tidak berkuasa untuk tunduk pada kebijakan yang dibuatnya. Jika masyarakat sebagai kelompok lemah tidak mau tunduk dengan kebijakan tersebut maka sebagaimana disebutkan di atas, masyarakat tersebut dianggap melanggar hukum oleh penguasa. Dalam situasi lain, kondisi berbeda mungkin saja terjadi, konflik dapat saja menghasilkan konsensus. Ketika masyarakat bersedia untuk menghasilkan kesepakatan bersama. Dalam hal ini, kesepakatan terjadi karena adanya negosiasi-negosiasi yang dihasilkan untuk menghasilkan konsensus ${ }^{30}$.

Dalam realitas sosial, konflik seringkali diasumsikan negatif. Dalam melakukan Analisa terhadap berbagai fenomena sosial, keberadaan konflik sosial dikonotasikan sebagai kondisi yang memilukan bagi sebagian kelompok sosial lainnya dalam masyarakat. Hal ini senada dengan pernyataan Wes Sharrock dalam Pip Jones yang mengemukakan bahwa, teori konflik memiliki dasar asumsi yang meyakini bahwa pada dasarnya masyarakat dapat memberikan kehidupan yang baik bagi orang lain, hanya saja realitas sosial menunjukkan bahwa sebagian orang tertindas ditekan sebab adanya perbedaan kepentingan. ${ }^{31} \mathrm{Hal}$ ini pada waktunya akan menimbulkan kesadaran di masyarakat bahwa perbedaan kepentingan di masyarakat sama pentingnya dengan kesepakatan atas aturan-aturan nilai. Perlu dilakukan negosiasinegosiasi antar kelompok masyarakat untuk mencapai konsensus. Dengan demikian, "secara realistis konflik dapat saja berimplikasi kepada ketidaknyamanan pada suatu perspektif, namun pada sisi lain hakikatnya merupakan antithesis yang bisa menimbulkan solusi atas suatu problematika sosial $^{32}$.

Konflik yang berujung kekerasan merupakan cikal bakal tumbangnya rezim orde baru. Berkaca pada asumsi teori konflik bahwa pada dasarnya konflik merupakan realitas sosial yang tidak dapat dihindari. Pada dasarnya konflik memiliki makna bipolar, di satu sisi konflik dapat menciptakan situasi dominasi dan eksploitasi atas kelas sosial tertentu, namun di sisi lain konflik

29 Ibid.

30 Tualeka, M. W. N. (2017). Teori Konflik Sosiologi Klasik Dan Modern. AlHikmah, 3(1), 32-48.

31 Pip Jones, Pengantar Teori-Teori Sosial dari Teori Fungsionalisme hingga PostModernisme, terjemahan Achmad Fedyani Saifuddin, Yayasan Obor Indonesia, 2009, Jakarta, hlm. 15.

${ }^{32}$ Masudi, M. (2015). AKAR-AKAR TEORI KONFLIK: Dialektika Konflk; Core Perubahan Sosial dalam Pandangan Karl Marx dan George Simmel. Fikrah, 3(1), 177-200. 
juga dapat menciptakan revolusi dalam kelompok-kelompok politik dengan orientasi melawan kelompok dominasi yang berkuasa ${ }^{33}$.

Runtuhnya rezim orde baru merupakan buah dari kompleksitas konflik yang terjadi di Indonesia hingga menimbulkan gerakan reformasi. Ketidakpuasan masyarakat terhadap penguasa orde baru yang bersikap sentralistik, diskriminatif dan mendikte, seiring waktu telah menggiring masyarakat pada kesadaran atas kebutuhan hukum dan keadilan yang mengakomodir masyarakat luas.

Keberadaan teori konflik tidak hanya bermanfaat dalam menganalisis cikal bakal konflik dan arah perubahan sosial yang terjadi sebagai reaksi atas langkah manajemen penanganan konflik. Teori konflik juga mampu memberikan konsep yang solutif dalam menghadirkan alternatif penanganan konflik sosial sebagai antithesisnya. Beberapa hal yang dapat dievaluasi sebagai langkah awal penangan konflik yang sejatinya merupakan realitas sosial yang tidak akan pernah hilang, diantaranya adalah:

1. Konflik merupakan akibat dari polarisasi yang terus terjadi di masyarakat. Untuk itu penting untuk terus menjaga dan meningkatkan komunikasi antar kelompok masyarakat yang terlibat konflik agar menghasilkan nilai-nilai toleransi dan konsensus sebagai perubahan sosial atas konflik yang terjadi;

2. Konflik terjadi akibat terhalangnya akses terhadap kebutuhan dasar atau kepentingan tertentu. Untuk itu kelompok dominasi perlu segera melakukan identifikasi atas kebutuhan kelompok yang didominasi, demi menghasilkan pilihan-pilihan solutif untuk memenuhi kebutuhan serta kepentingan antar kelompok;

3. Konflik juga dapat terjadi akibat posisi yang tidak selaras, serta perbedaan pandangan atas konflik yang terjadi antar kelompok yang terlibat konflik. Dalam hal ini biasanya memerlukan pihak ketiga dalam mengupayakan proses negosiasi demi menghasilkan kesepakatan yang menguntungkan kedua belah pihak;

4. Konflik dapat terjadi akibat ketidaksetaraan dan ketidakadilan yang muncul sebagai masalah sosial. Sebagai solusinya, perlu dilakukan perubahan struktur dan kerangka kerja yang berpotensi menimbulkan kesenjangan antar kelompok yang terlibat konflik, seraya mengembangkan sistem yang mampu meningkatkan jalinan komunikasi antara kelompok yang terlibat konflik;

33 Jonathan H. Turner, The Structure of Sociological Theory, The Dorsey Pers, 1975, Illinois, hlm. 84. 


\section{Penutup}

\section{Kesimpulan :}

Pertama, konsep teori konflik menyadarkan bahwa konflik merupakan realitas sosial yang tidak dapat dihindari. Konflik tidak selalu berkonotasi negatif, sebab dalam situasi tertentu konflik justru dibutuhkan untuk mencapai perubahan sosial dalam masyarakat. Penanganan konflik yang buruk dapat mengakibatkan gejolak sosial yang mengarah pada kekerasan, sebagaimana yang terjadi pada tumbangnya rezim orde baru. Merujuk pada asumsi teori konflik, maka penyebab tumbangnya rezim orde baru dapat dipetakan dalam beberapa hal, diantaranya; pertama, sikap rezim orde baru yang mendominasi pembuatan dan penegakan hukum; kedua, penerapan produk hukum penguasa orde baru sebagai standar hukum dalam bertingkah laku, mengandalkan paksaan yang membuat anggota masyarakat yang didominasi tetap bertingkah laku sesuai dengan norma kelompoknya; ketiga, dominasi penguasa rezim orde baru dalam pembuatan dan penegakan hukum membuat kelompok masyarakat yang didominasi mempertanyakan proses pembuatan hukum itu sendiri; keempat, ketiadaan ruang-ruang negosiasi antar kelompok penguasa dan masayarakat semakin menjauhkan masingmasing kelompok yang terlibat konflik dari peluang konsensus; kelima, ketiadaan konsensus menyadarkan anggota kelompok masyarakat dalam memperjuangkan keadilan atas kebutuhan dasar dan kepentingan kelompoknya; keenam, penggunaan upaya represif sebagai solusi atas suara kepentingan kelompok masyarakat yang didominasi, seiring waktu telah memunculkan gejolak perlawanan sebagai upaya kelompok masyarakat memperoleh kebutuhan dan kepentingannya.

\section{Saran}

Pertama, konflik antara kelompok masyarakat berdasarkan kekuasaan merupakan realitas sosial yang tidak dapat dihindari, untuk itu evaluasi atas relasi kekuasaan pada rezim orde baru perlu terus dilakukan oleh kelompok pemegang kekuasaan saat ini dan yang akan dating, guna menghindari terulangnya konflik sosial yang berujung pada gejolak kekerasan. Kedua, hasil evaluasi yang didapat dari penggunan antithesis teori konflik selayaknya dijadikan rujukan bagi pemegang kekuasaan selanjutnya dalam merumuskan solusi yang mampu menghadirkan konflik sosial yang membangun menuju perubahan sosial yang diharapkan oleh setiap kelompok masyarakat yang berkepentingan 


\section{Daftar Pustaka}

Buku

Abdul Jamil Wahab, Manajemen Konflik Keagamaan; Analisis latar Belakang Konflik Keagamaan Aktual, Elex Media Komputindo KompasGramedia, 2014, Jakarta.

B. R. Pudya, Timbulnya Gerakan Reformasi 1998 di Indonesia, Ganesha Study Club, http://pelitabaraapi.blogspot.com, diakses pada 13 Desember 2009.

Freda Adler, et all, Criminology, McGraw-Hill, 1991, New York.

Judistira K Garna dalam Disertasi Sunarta, Integrasi dan Konflik: Kedudukan Politik Jawara dan Ulama dalam Budaya Politik Lokal, PPS UNPAD Bandung, 1997, Bandung.

Jonathan H. Turner, The Structure of Sociological Theory, The Dorsey Pers, 1975, Illinois.

Kamanto Sunarto, Pengantar Sosiologi, Lembaga Penerbit fakultas Ekonomi Universitas Indonesia, 2004, Jakarta.

Munir Fuady, Teori-Teori Besar (Grand Theory) Dalam Hukum, Kencana Prennamdeia Group, 2013, Jakarta.

Novri Susan, Sosiologi Konflik: Isu-Isu Konflik kontemporer, Kencana, 2009, Jakarta, Cetakan Pertama.

Pip Jones, Pengantar Teori-Teori Sosial dari Teori Fungsionalisme hingga Post-Modernisme, terjemahan Achmad Fedyani Saifuddin, Yayasan Obor Indonesia, 2009, Jakarta.

Ronald L. Akers, Criminological Theories, Fitzroy Dearborn Publishers, 1999, London.

Topo Santoso dan Eva Achjani Zulfa, Kriminologi, PT RajaGrafindo Persada, 2004, Jakarta, Cet. Ke-4.

Jurnal

Abdi, S. (2007). Muslim Politics and Democracy in Indonesia. Millah: Jurnal Studi Agama, 7(1).

Diharjo, S. M. (2019). DINAMIKA PERUBAHAN SOSIAL DALAM TEORI KONFLIK. Jurnal Ilmu Komunikasi dan Bisnis, 5(1).

Lathif, N. (2017). TEORI HUKUM SEBAGAI SARANA ALAT UNTUK MEMPERBAHARUI ATAU MEREKAYASA MASYARAKAT. PAKUAN LAW REVIEW, 3(1). 
Masudi, M. (2015). AKAR-AKAR TEORI KONFLIK: Dialektika Konflk; Core Perubahan Sosial dalam Pandangan Karl Marx dan George Simmel. Fikrah, 3(1).

Muhamad Zuldin, M. (2019). Ketimpangan Sebagai Penyebab Konflik: Kajian atas Teori Sosial Kontemporer. TEMALI: Jurnal Pembangunan Sosial, 2(1).

Oktaviani, J., \& Pramadya, T. P. Model Negara Kekuasaan: Orde Baru dalam Tinjauan Pemikiran Hobbes dan Niccolo Machiavelli. Indonesian Perspective, 4(2).

Pratikno, P. (1998). Keretakan Otoritarianisme Orde Baru dan Prospek Demokratisasi. Jurnal Ilmu Sosial dan Ilmu Politik, 2(2).

Purwoko, B. (2016). Bureaucracy and the Politics of Identity: A Study on the Influence of Ethnicity on the Bureaucrat Recruitment Process in Sorong Selatan Regency, West Papua, Indonesia. Indonesian Journal of Government and Politics, 7(4).

Sukardi. (2016).Penanganan Konflik Sosial Dengan Pendekatan Keadilan Restoratif. Jurnal Hukum dan Pembangunan, 46(1).

Syahputra, M. A. D., \& Mahdiana, N. Analisis Buku Teks Sejarah terkait Materi Nasionalisme Dengan Pendekatan Teori Nasionalisme Benedict Anderson. HISTORIKA, 22(2).

Syukur, I. (2013). Adat Community in the Village Government: State and Society Relations in Indonesia. ASAS, 5(1).

Tualeka, M. W. N. (2017). Teori Konflik Sosiologi Klasik Dan Modern. AlHikmah, 3(1).

Zuhro, R. S. (2016). Good Governance dan Reformasi Birokrasi di Indonesia. Jurnal Penelitian Politik, 7(1). 